\title{
The Investigation of Sinop Coastal Area Pattern in Terms of Coastal Management
}

\author{
Assist. Prof. Dr. Oylum Gokkurt Baki (Corresponding author) \\ Department of Environmental Engineering, Engineering and Architecture Faculty \\ Sinop University, Sinop, Turkey
}

Tel: 90-368-271-4151Ｅ-mail: oylumbaki@gmail.com

Professor Osman Nuri Ergun

Dept. of Environmental Engineering, Ondokuz Mayis University, Samsun, Turkey

Tel: 1-90-362-312-1919Ｅ-mail: onergun@ omu.edu.tr

Received: March 21, 2017 Accepted: April 15, 2017

doi:10.5296/emsd.v6i2.11241ＵRL: https://doi.org/10.5296/emsd.v6i2.11241

\begin{abstract}
Sinop is a province located at the Black Sea region and it is rich in scenic beauty and cultural values and has potential touristic resources. Moreover, it is one of the most prominent port towns in the Black Sea region. The area, which can be qualified as the most important and prominent image region of the city, comprise the coastal land use line of the province. However, the city fails to utilize this advantage.

The master plan of the city has substantially changed through the years. The present study aimed to determine the changes in the master plans of the city through the years, the distribution of the coastal land use areas and changes in the utilization of the coastal areas through the years. Evaluating the current administrative competence/constraints in the coastal area with respect to the data obtained in the study is also among the goals of the study. Furthermore, by taking the impact of environmental factors on the ratio of the land use areas into consideration, examining these data in terms of coastal management planning to create habitats that better suit the vital requirements is another prospect of the study.

In addition, the evaluation of some coastal area-associated issues including the extent of the effect of current erosion issues on the development of the coastal area was also included in the study. The percentage of the current functional coastal areas in the province, the distribution of the number of building floors and the changes in these data by years were also
\end{abstract}


investigated. For these evaluations, zoning revisions and 1/2000, 1/5000 and 1/10000 maps were examined to determine the coastal area zoning changes and filling areas. Fieldworks were carried out in the coastal area of the city to determine and observe the state of the area. The data was collected by contacting relevant institutions and organizations and carrying out fieldworks. Considering the data obtained in the study, measures to remedy the zoning deficiencies in the coastal area and the city center were proposed.

The obtained data and evaluations obtained revealed that the province is in need of new and sustainable planning and there is a necessity to include implementations that are based on integrated coastal area management principals.

Keywords: Coastal city, Coastal planning, Coastal management, Sustainability, Black Sea, Sinop

\section{Introduction}

Coasts are fragile areas that connect the land to the sea and have always been a focus of human greed. These areas have caused irregular urbanization for many years. A coast is more of a social area than a physical area (Doğan and Erginöz, 1997).

Half of the human inhabitants of the world are known to be settled along the rivers, at river-mouths or at sea or lake shores. Majority of the cities with over half million population are located along the shores; the half of the most populated city, with over 4 million population, is located at the coastal areas and areas around the river-mouth; most of the other highly populated cities are established at the shores of deltas and large lakes and over large rivers (Hudson, 1996; Arslan, 2005).

Physical geography, especially geological-geomorphological and hydrographic factors, and human geography factors (main reasons behind city establishments, city master plans, religious factors, customs and traditions, the socio-economic status of city population) play active roles in the formation of settlement plans (Bekdemir, 2007; Bayhan, 1969).

Urbanization is the outward growth from the city center and renewal and reformation of the current fabric of city centers so that they better suit the contemporary needs. Unplanned and irregular urbanization is devoid of aesthetic concerns, indifferent to the harmony between human and environment and fails to remedy infrastructure, water, road and sewage problems and therefore, hinders establishing meaningful lifestyles (Bekdemir, 2007). Lamberti and Zanuttigh (2005), in their study, stated that the aim must be to introduce an integrated approach to coast management. They put emphasis on the necessity of carrying out multidisciplinary studies and mentioned that a large proportion of the coastal areas in Italy was under the risk of erosion and collaborative data documentation for engineering, socioeconomic and ecological indicators, especially in these regions, was an ongoing process. In another study, Tenikler (2001) reported the importance of coasts in terms of sustainability, threats posed to coastal land use and the administrative, legal and institutional problems attached to coast management and they discussed the issues on the Bay of İzmir scale. They mentioned that measures have been taken to form a management model that is based on mutual interaction to obtain sustainability. In their study, Erginöz (1998) examined the coastal 
area management in some Mediterranean countries and emphasized the importance of preserving the ecological balance during the urbanization of coasts to establish new hotels, motels and holiday resorts to meet the demands of the increasing tourist population. They also put emphasis on the necessity of establishing a connection between development programs and natural spaces. In another study by Büyükvelioğlu (1998), the developments and issues in coastal areas of the world and Turkey were investigated by sharing general and specific examples. This study mainly focuses on how rapid development of coastal cities and urban areas, the increasing problems in planning and management, the insufficient protection of coastal resources and failure at balancing the capacity use can exhaust the means of sustainability.

The extremely slow urbanization before the 1950s has accelerated after 1950, especially due to rural-urban migration. After 1980, two other important factors that shape urbanization have emerged. One of these factors is tourism (Iş1k, 2005). Accordingly, the situation assessment of Sinop, which is, especially in the recent years, on the road to realize its potential as a touristic attraction, was carried out in the present study.

The study includes land distribution, management and development of functional utilization of the coastal areas of the Sinop Peninsula, an important coastal city with an important touristic potential for the Black Sea region, throughout years. Furthermore, plans and recommendations were offered, aiming to determine the problems that emerge during coast utilization and obtain sustainable development by coast protection and management.

\section{Materials and Methods}

\subsection{Materials}

Sinop is located on the Boztepe Peninsula, which narrows towards the north from the Black Sea coastline. The mainland of the province is in the transition zone between the western and eastern Black Sea regions and located between 41.2 and 43.5 degrees north latitude and 34.5 and 35.5 degrees east longitude. Its total area is approximately $5842 \mathrm{~km}^{2}$ and $300 \mathrm{~km}$ of its $475 \mathrm{~km}$-long border is land, whereas $175 \mathrm{~km}$ of its borders is sea (EUD, 2016). The population density of the province is 48 people $/ \mathrm{km}^{2}$. Sinop is connected to Samsun through its coastal road and connected to the Turkish highway network through Kastamonu-Samsun road connection. It also has air and sea transportations. Sinop shows a controlled development due to being located at the most northern point of Turkey and having a blind spot in terms of transportation. Its location has caused its city center to develop with a closed and non-productive model, leading Sinop to become one of the cities with high out-migration rates in Turkey. The economic structure of Sinop shows that it develops as a closed and non-productive model due to the late arrival of transportation and its insufficiency. Sinop is also underdeveloped in terms of industrialization.

With its rich woodland and potential for sea and culture tourism, Sinop has strong advantages that are waiting to be utilized in its development. The total number of tourists, both foreign and domestic, increased by around 400000 people ( 3 months total data) in the summer season, especially during the last five years. 


\section{Macrothink}

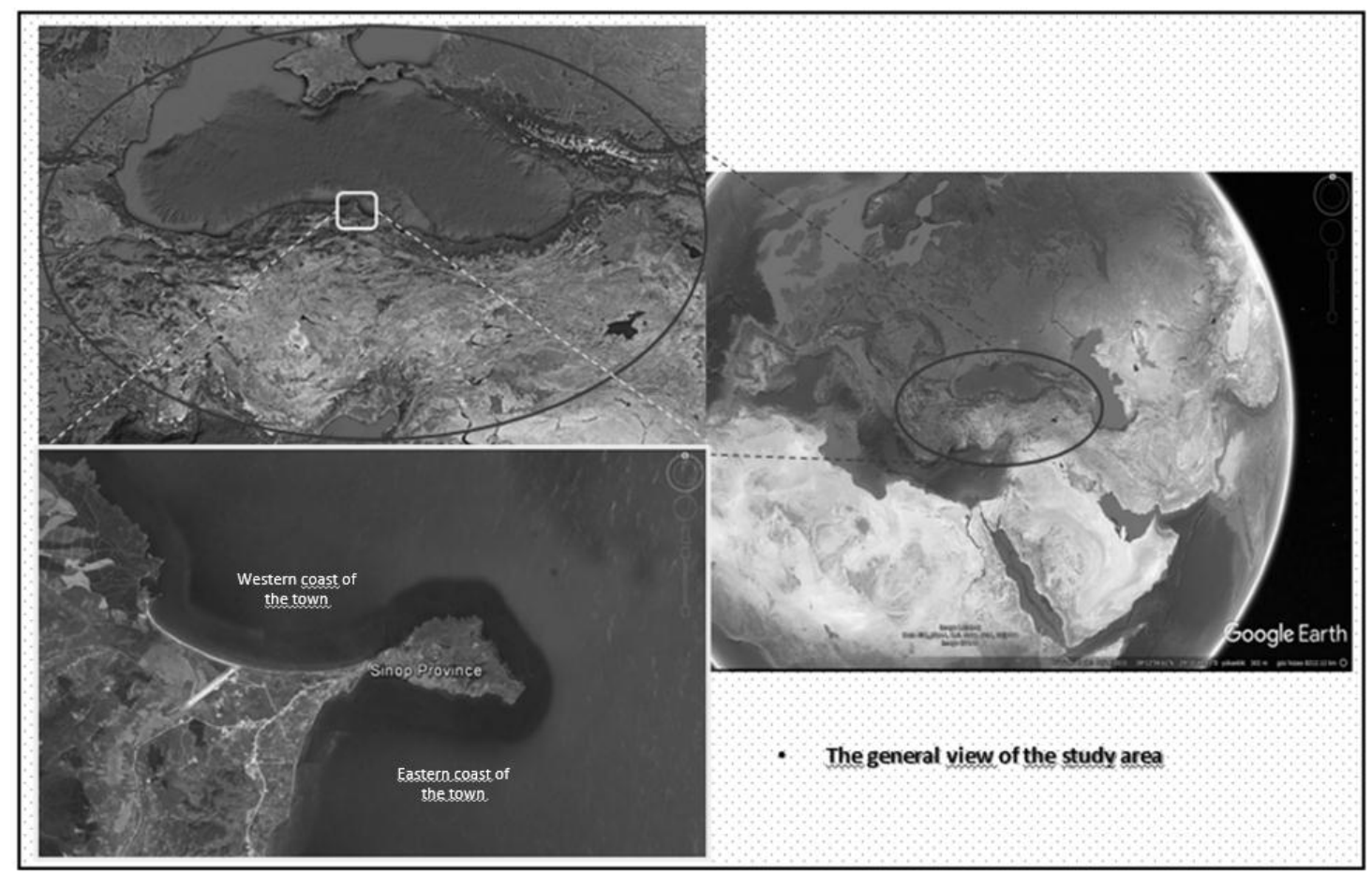

Figure 1 . The general view of the study area

Sinop is situated on the saddle-type topographic area located at the narrowest point of a peninsula with a very thin neck. The neck extends towards the sea with slopes ranging between $5 \%$ and $15 \%$ in the north and south directions. In the urban residential area, there are very steep precipices at the northern part of the seashore. In the south, the natural harbor line shows comparatively smooth slopes. In the east-west direction, the slopes increase towards the east and in the north-south direction, the slopes increase towards the south. The inner harbor on the southern side of the peninsula, with its non-windy location and calm sea, is the most important port of southern Black Sea region. Throughout history, this port has been a host to busy harbor and shipyard activities (MEF, 2009).

In the current land use of the city, residential areas are located at the parts starting from the narrowest part of the peninsula and widening towards the east. The present study showed that the land use distribution and especially the distribution of the residential areas were determined based on the meteorological properties and topographic structure.

\subsection{Methods}

In the present study, a field study in the coastal area of the city was performed to determine and to observe the state of the city. Data was collected by contacting relevant institutions and organizations and carrying out fieldworks. Determining the intended use and percentages of areas where the city expands or areas that are open to zoning are highly important to determine the suitability of the coasts for use. Therefore, priority was given to obtain the reports on the Sinop province master plan and reports on changes in the master plan. The land use distribution, sufficiency and quality of the province were determined with on-site evaluations. 


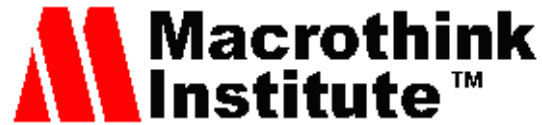

The main purpose of obtaining the master plan of the province is to determine whether the province shows a development that complies with the town planning principles, in terms of sustainable coast management principles. For this study, zoning revisions and 1/2000, 1/5000 and 1/10000 maps were examined to specify the coastal area zoning changes and filling areas. In addition, the private interviews with state institution officials gave further insight into the evaluations for the coastal area use. The current state of the planning and its shortcomings were determined by showing the proper arrangements and projections on the provided maps.

\section{Results}

\subsection{Zoning Applications in the Coastal Area of Sinop Province}

The first master plan of the city was developed in 1960 by the Provincial Bank and revised in 1977. The master plan was revised in 1988 and in 2017, the digitization of the revised plan was commenced. The Central District of Sinop has three master plans and revisions comprising the plans and revisions developed in 1960, 1977 and 1988; however, there is no registered document on the plan developed in 1960. The master plans were approved in 1988 and aimed to achieve a settlement for 63892 people in 2005.

The examination of the master plan can be divided into two parts: $(i)$ the revision of the current master plan and (ii) additional master plans (MSU, 2005). Both studies were carried out by considering the touristic potential and commercial and spatial potential of the coastal land settlement. It was seen that implementations were carried out to utilize the areas deemed inconvenient for settlement due to their geological properties as green areas. Again, the historical monuments in the settlement area were put under protection and reserved as heritage sites.

According to 1977 Master Plan, the western region of the province was determined to be the zoning area. However, since the ground in this region was inconvenient for settlement, the zoning area was changed to the eastern region of the province. The general analysis of urban land use showed that the active green areas were insufficient and the distribution of the current development was not homogenous. The active green areas (parks, children's parks and playgrounds) severely fell short either in their distribution within the cityscape or in their numbers.

Sinop, either due to its location on the peninsula saddle or the long-term location of its settlement areas at the narrowest neck of the city, has a significantly congested fabric. The plan revision developed for the areas covered by 1988 Master Plan contain the following highlights:

1. The existing master plan (in 1977) had failed to meet the demands of official institutions.

2. Areas reserved for craftsmanship should be located in a congested area and this area should be selected among the areas located in the small industrial bazaar outside the settlement areas.

3. There is a requirement to re-arrange the road network proposed in the current master plan to meet the contemporary needs such as adaptation of road width to regulations. 


\section{Macrothink}

Environmental Management and Sustainable Development

ISSN 2164-7682

2017, Vol. 6, No. 2

4. Tourism-oriented development and the consequent demands are required to be regarded by the master plan

5. The fact that the residential areas opened in the western region of the city in accordance with the current master plan had encountered landslide issues aroused the need to conduct revision studies.

Figure 1 shows the land use ratios prospected by the revised master plan of Sinop.

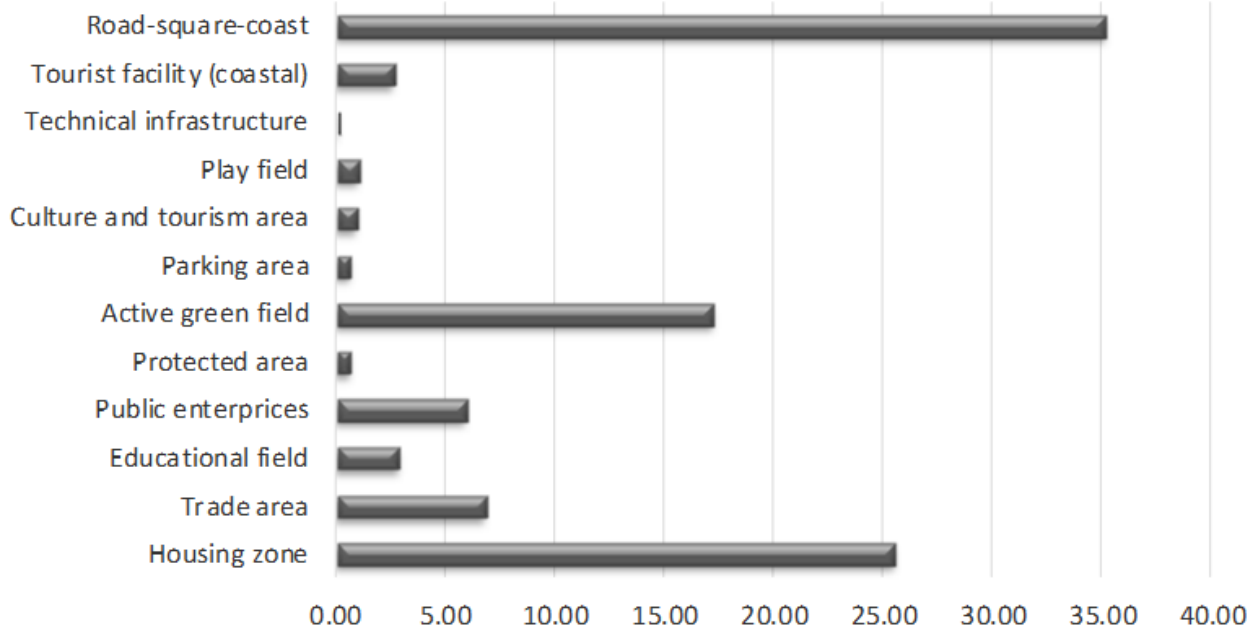

Figure 1. The land use ratios prospected by the revised master plan of Sinop (1988)

- Areas not connected to the coast are excluded from figure. Only the areas located in the coastal area are included.

The joint land use areas and standards of revised and additional master plans are given in Table 1.

The highlights regarding the regulation of green areas in the additional development and revision plans proposed in 1988 were as follows:

a. The areas determined as green areas in the current master plan should be generally protected; the areas in which such implementations can no longer were applicable or the altered areas should be removed,

b. Decisions that proposed function shifts affecting the macroform of the city should also include settling new green areas.

- In the additional development and revision plans, examining the active green area concept in the planning area was deemed necessary. Green areas were divided into three main groups:

a. Green areas that do not include recreational facilities (these areas appeal to the eye, and are used in relieving the congested fabric of the city and providing ease of arrangement for other uses),

b. Green areas including recreational facilities such as parks, children's parks and 


\section{Macrothink}

playgrounds,

c. Green areas that complement the utilization of sea (these areas complement the sea tourism, beach areas, serve as recreational areas, and camping sites to the overpopulation that mostly occur during summer)

Table 1. The Joint Land Use Areas and Standards of the Revised and Additional Master Plans (Uçkun, 1988)

\begin{tabular}{|l|c|c|c|}
\hline Land use type & Area(ha) & $\mathbf{~ m}^{\mathbf{2}} /$ person & \% Land use \\
\hline Residential area & 285.22 & 40.34 & 49.97 \\
\hline Commercial area & 23.20 & 3.63 & 4.06 \\
\hline Official institutions & 22.42 & 3.50 & 3.93 \\
\hline Education & 19.54 & 3.05 & 3.42 \\
\hline Active green area & 67.35 & 10.52 & 11.80 \\
\hline Sports facilities & 4.55 & 0.55 & 0.62 \\
\hline Tourism area & 20.55 & 3.21 & 3.60 \\
\hline Technical infrastructure & 1.43 & 0.22 & 0.25 \\
\hline Woodland & 54.34 & 8.49 & 9.54 \\
\hline Parking area & 2.48 & 0.39 & 0.43 \\
\hline Road, common place, coast & 52.50 & 8.20 & 9.20 \\
\hline Total & $\mathbf{5 7 0 . 7 4}$ & - & $\mathbf{1 0 0 . 0 0}$ \\
\hline
\end{tabular}

Areas not connected to the coast are excluded. Only the areas located in the coastal area are included.

The abovementioned highlights showed that the ratio of green areas in the central settlement area was low and increased with revision (Figure 2). Active green areas after revision was $10.52 \mathrm{~m}^{2} /$ person (Table 1). The decisions mostly involved the protection of areas in the eastern parts of the coast, especially the areas under the risk of erosion and sustaining these areas as green areas.

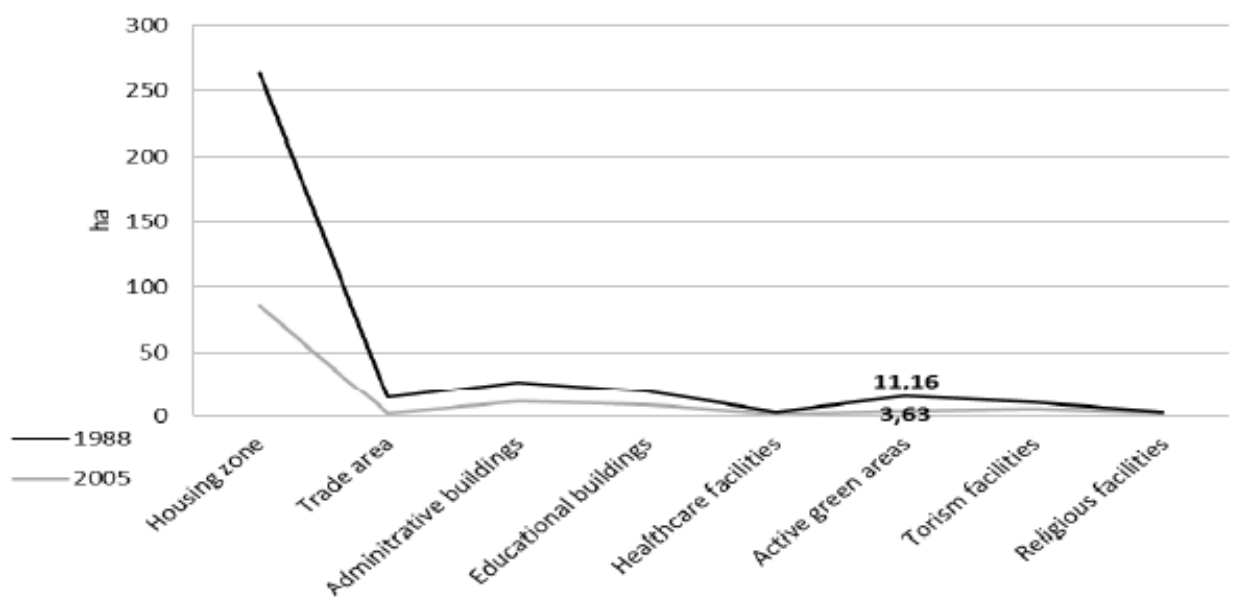

Figure 2. The changes of general land use areas in city center in 1988 and 2005 


\section{$\triangle 1$ Macrothink}

Figure 2 shows the values determined in the most recent revision study and the changes in land use distribution determined in 2005. As it can also be seen in the implementation, albeit the western regions were decided to be the new development area, new settlement formations are towards the east of the city.

There are currently eight districts in the city (Figure 3). As of 2016, four central villages were added to the city center as districts. These districts have approximately $85 \%$ share in the coastal areas; therefore, the development properties of these districts most areas located in the coastal area were also examined by considering the current issues of the coastal areas. As it is seen in Figure 4, there are various factors that can affect the housing distribution by districts, and soil properties (geological properties) and meteorological factors caused problems in the coastal areas of the city are among these factors.

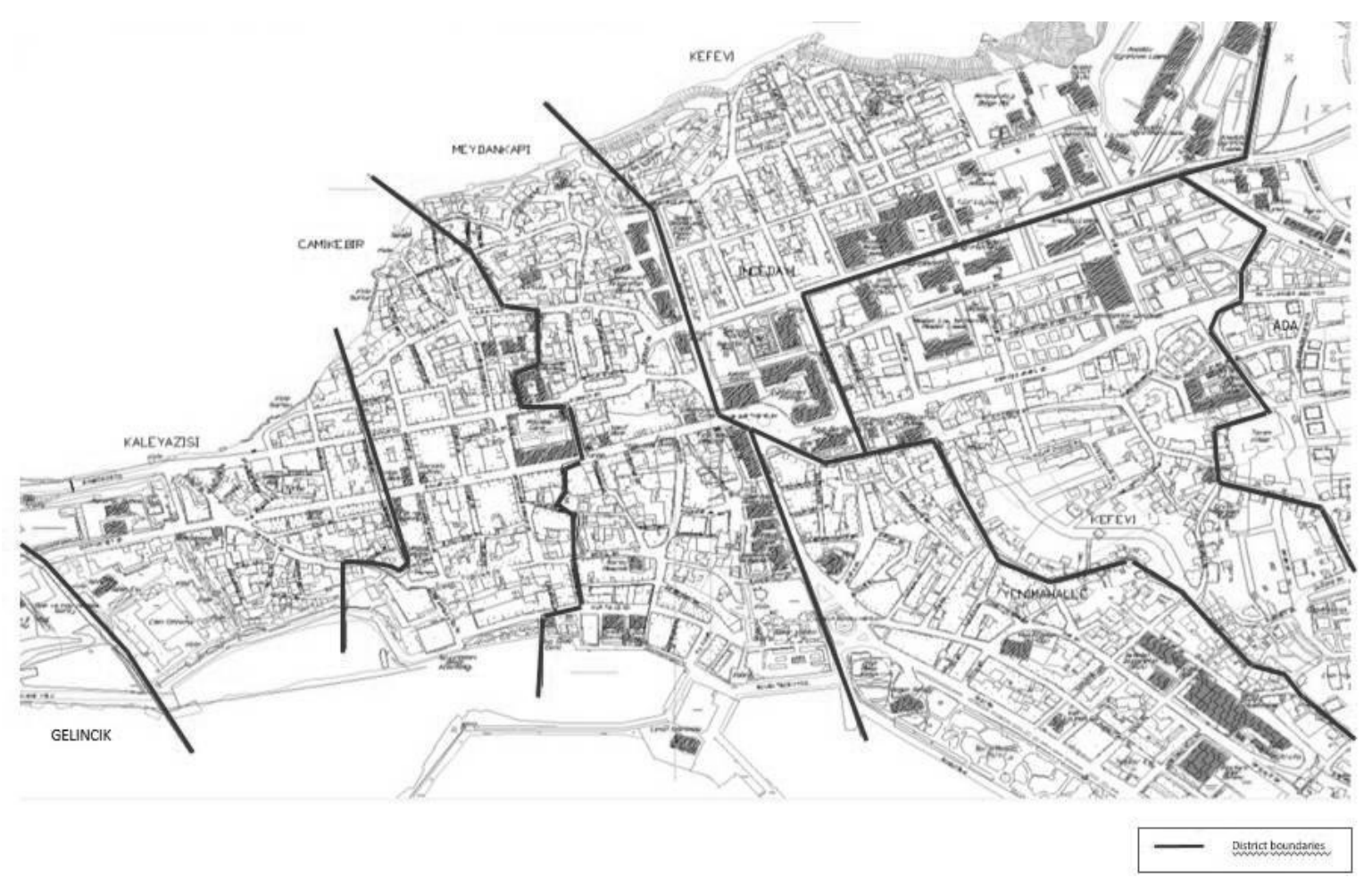

Figure 3. The map of the distribution and borders of districts in the city center

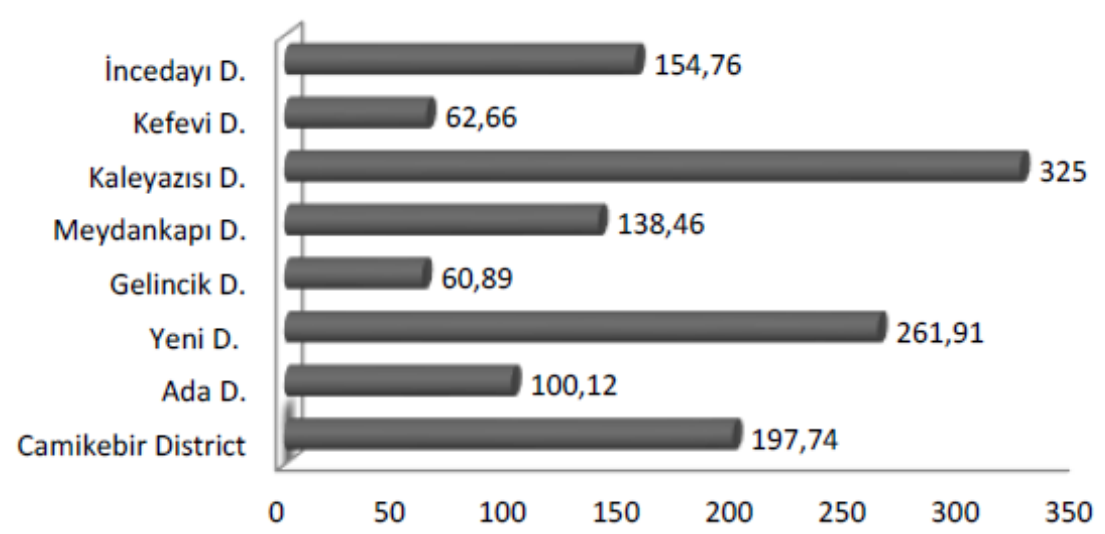

Figure 4. Housing distribution (housing/hektar) among districts in city center in 2005 


\section{Macrothink}

Figure 5 shows the current housing distribution and numbers by districts. To maintain the current fabric of the city, the new housings like the precedent structures in the new development areas can only be allowed to have 3 floors on average, and 4-5 floors, at maximum

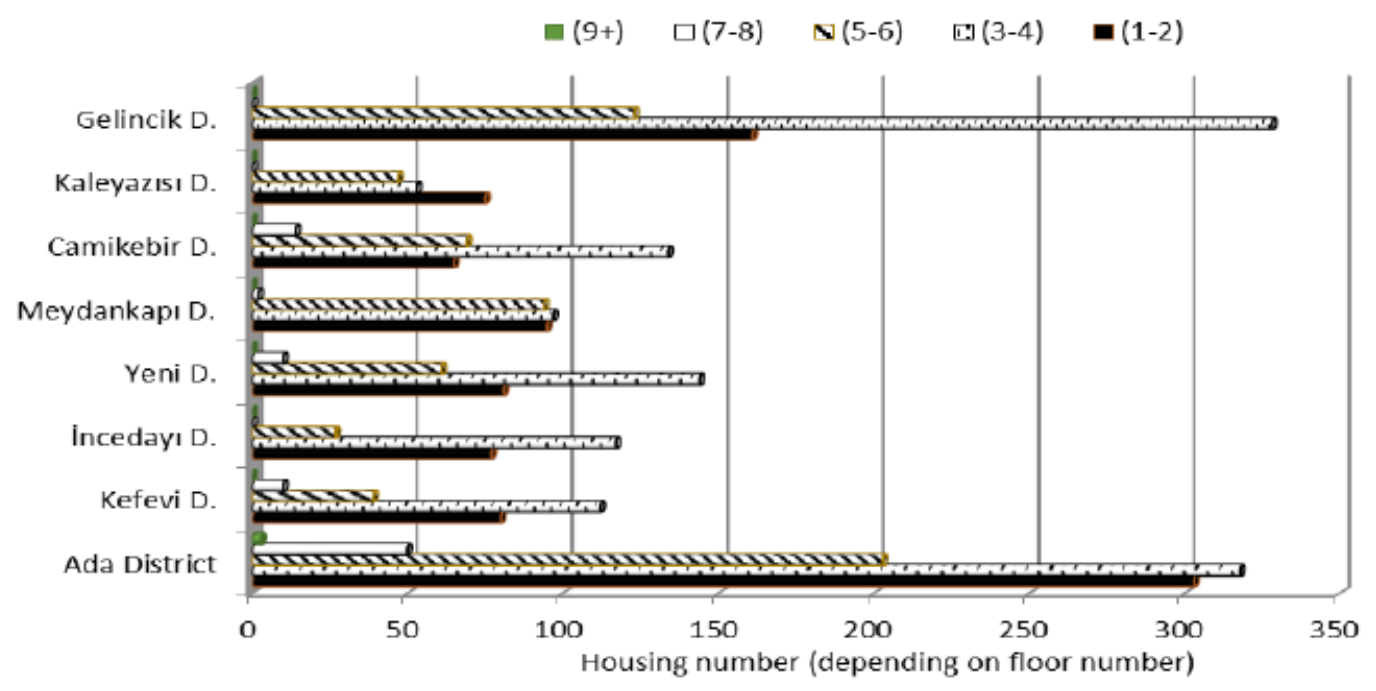

Figure 5. The distribution of the number of building floors by districts in the city center

In decisions and revisions made after the revision study in 1988, it was emphasized that the existing tourism facilities in the southern shore of the city were preserved and were to be preserved and no structuring will be allowed in the shore, albeit hotels, motels, hostels and one-day sea uses are allowed.

To avoid the occurrence of the soil movements already occurred in the west coast of the city in the other parts of the city, the soil movements in the specified regions, especially in coastal areas, necessitated to restrict the number of building floors. Forestation studies are required in these regions as means of protection. Construction measures should also meet the requirements resulting from the soil structure in this type of areas. In other words, it was projected that this area should only contain low-rise service unites that respond to the summer tourism and shore utilization-oriented touristic facilities, such as camping sites. For this type of uses in the specified areas, it was especially highlighted in the plan conditions that the soil structure must be determined and the construction can only be allowed after technical examination of the construction and infrastructure conditions and approval of the responsible engineer.

Continuing the commercial region with green area, the region behind the harbor in city center, in the west direction will provide Sinop with development areas for tourism. For this purpose, it was projected that the area behind the harbor will be opened to commercial uses (diners, cafes, motels and hotels) that have green areas, and a pedestrian walkway will also be included in this area. The said pedestrian walkway was built in the summer of 2016.

In the revised master plan, the total active green areas containing parks, children's parks and 


\section{MInstitute Macrink $_{\text {Ins }}$}

playgrounds is approximately 11 hectares. The total areas recommended for forestation and utilization as recreational areas or camping sites is around 39 hectares. In the revised master plan, when the projected population and planned active green areas are considered, green area per a person is $11.6 \mathrm{~m}^{2}$. This value is above the threshold specified by the Zoning Law as 7 $\mathrm{m}^{2}$ /person (Official Journal (o.j), 1985).

\subsubsection{Filling Areas of the Province}

Determination of filling areas of the city is important in terms of coastal use and it is mandated by Law No. 3621 Law name Coastal Law (Official Journal (o.j), 1990). The quality and quantity of the filling areas can affect most of the properties of a filling area. When the coastal area is viewed as a harbor for all living creatures at micro and macro scale, they gain further importance. These factors necessitated to determine the filling areas in the province and to evaluate the physical changes caused by filling areas by analyzing their photographs from past years. In the city center and its vicinity, 15 filling cancellation and registration lawsuits were filed, mostly in 1981, and following these lawsuits, lawsuits to destruct the buildings that were illegally built on the coast and coastline were filed and concluded. There are also lawsuits filed by the Treasury for the cancellation of land registry records of some immovables (on behalf of individuals) located on the coastline for some of the existing filling areas. The examinations made within this context showed that most of the cases have been concluded in favor of the public. The filling areas in the city center are given in Figure 6 (G. Koşar, personal communication, 2010). Twelve lawsuits were also filed in 1984 to prevent the intervention in the coastal area and were concluded in 1991-1992. The examination of the context of the cases showed that lawsuits were usually filed by individuals claiming the rights to have the registry of the areas in the coast and coastline under their own names and most of the lawsuits were concluded in favor of the public (Gökkurt Baki and Ergun, 2016).

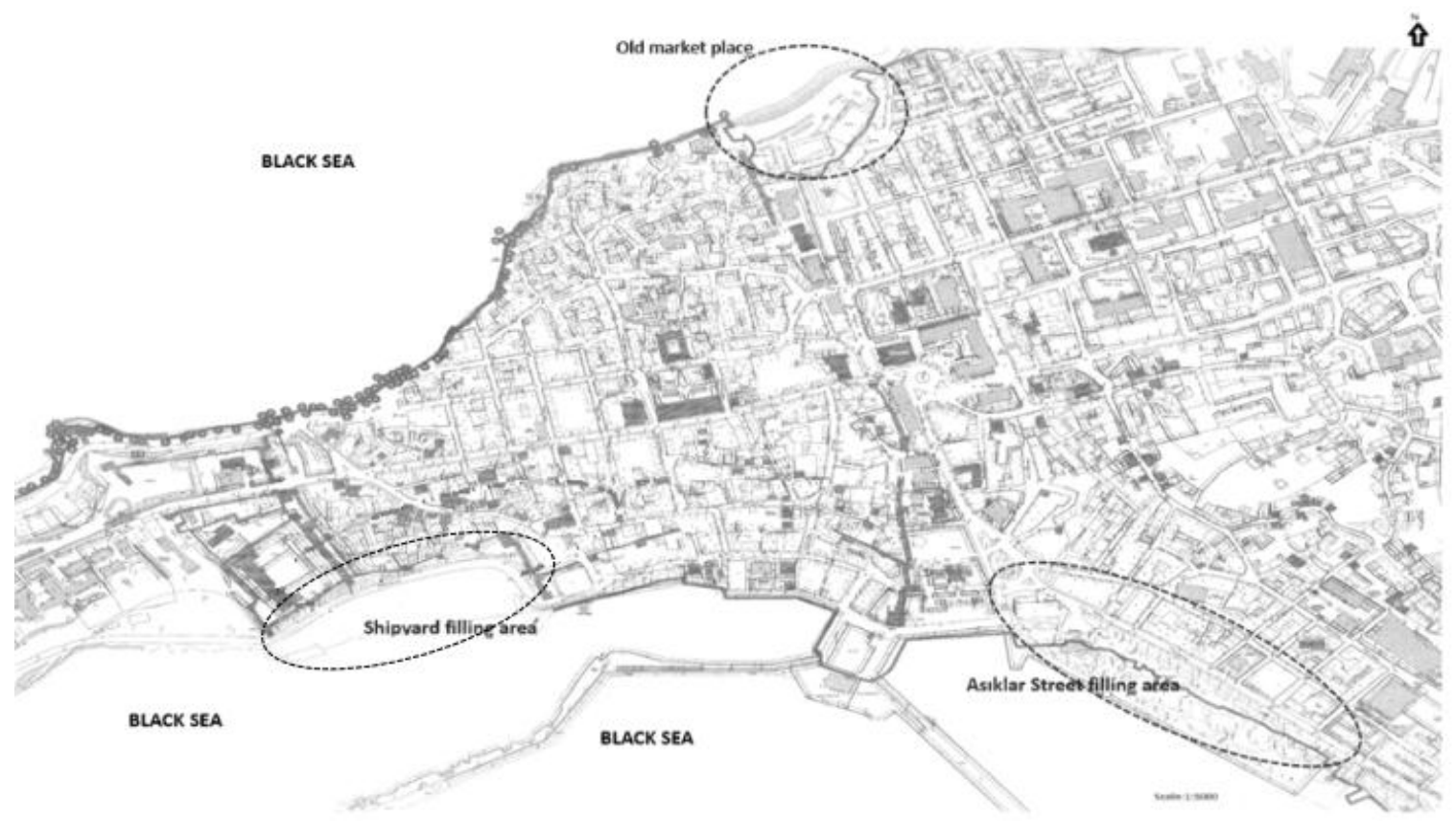

Figure 6. The figure of some filling areas located in the southern and northern city centers 
In 2006, the Ministry of Culture and Tourism Samsun Cultural and Natural Heritage Conservation District Board declared the province shores as 1st Degree Archaeological Site. Within this context, according to the detailed underwater surveys conducted in the protection areas of Sinop Harbor, it was decided to register the areas where diving is prohibited by the decision No. 2001/2952 of the Council of Ministers and the areas where wrecks are processed as 1st degree archeological site areas under the Law no. 3386 and 5226 and 2863 (DCT, 2006). With this decision, filling area in the areas specified by the law was prohibited.

\section{Conclusion}

The preferability of coastal areas has been depending on various factors for many years. One of the most important factors is undoubtedly the unique beauty of coastal areas. This beauty can only be sustained with good and integrated coastal management. Accordingly, the urbanization process in the city should be continued without deteriorating the natural fabric of the city and the environmental factors. Rapid population growth and the location of Sinop caused the narrowing of the urban fabric, and because of unplanned urbanization, today, areas with very low urban standards have been formed in most places. However, the city has gradually begun to develop towards its western and southern parts, and the development in these directions continues.

At some points in the inner parts of the city, an organic fabric is dominant, and the protection of this fabric is also considered important. Historical fabrics on the high ridges are pushed behind in terms of protecting the aesthetic due to the excessive allowance for constructional precedent (up to 11 floors). Conservation decisions should be taken in these areas and constructions should be reviewed and supervised.

Both the main street and the toll roads in the province are very narrow due to the fact that they were built a long time ago. The area separated as the traffic surface cannot meet today's conditions. In addition, the high ground rents in the city center caused congested and dense residential areas.

Constructions allowed in coastal areas are specified in the Coastal Law. However, there is no clarity as to how these constructions should be planned. It is not appropriate to talk about the use of coastal areas for the benefit of the community without planning in national, regional and local scales on how to benefit from coastal areas. The constant changes made in the Coastal Law aimed at expanding the coastline to increase land and public use have also created a planning problem. To overcome this problem, the use of coasts, coastlines and filling areas should be clarified.

It was seen in the study that filling areas and the use of these areas as green areas have been maintained and the data for the green area for 2005 was determined to be much higher than that for 1998. In addition, in the areas where the houses were or going to be in the city center or in the eastern part of city, which is the expansion area of the city, areas should be left as required by the relevant regulations. In this way, transforming the city's surroundings into green areas will prevent the fertile soil from being destroyed by erosion, which is a problem on the provincial coasts, and will enable the formation of a large oxygen reservoir that will 
frequently renew the city's polluted air.

Examining the distribution of the usage areas in the province master plan and the data of the master plan proposed in 2016 showed that that these plans included increasing the forest areas by $8.6 \%$, increasing the area of the children's playgrounds to 12.42 ha, increasing park-garden areas by $3 \%$, increasing the recreational areas by $30 \%$ and increasing the excursion sites to a total of 11 ha. If the existing proposals are put into practice, the city will possibly be subjected to a serious regulation in terms of area uses.

The headlines that cause problems in Sinop city coastal land use are coastal erosion, discharge of used waters, intensive tourism uses and partial filling areas. The coastal area use in the city take up almost $85 \%$ of the entire surface area of the city, which is quite large. Therefore, considering all the problems mentioned above, it is necessary to determine the most appropriate form of management for Sinop, which is a typical coastal city. While this type of management is determined, multi-disciplinary studies are needed (Gökkurt Baki et al., 2015).

Instead of preferring rapid and unplanned urbanization only with economic development intentions, integrated coastal management planning, which aims at eliminating basic and compulsory requirements based on communal and environmental solidarity, should be the first choice. Accordingly, not only economic targets but also social and environmental targets should be considered in an optimum way. This is the only possible way to maintain sustainable urban development and use.

\section{Acknowledgments}

We would like to thank Sinop Municipality staff for their verbal and written opinions regarding the archive and current data.

\section{References}

Arslan, D. (2005). Assessment of urban open spaces in the redevelopment process of coastal areas-Istanbul case. Master's thesis, Bahçeşehir University. Institue of Science. Architectural Department. İstanbul Turkey.

Bayhan, İ. H. (1969). City planning. İskender Press. İstanbul Turkey.

Bekdemir, Ü. (2007). Black Sea coastal cities (Samsun-Hopa). Çizgi Bookstore, ISBN:978-9944-272-07-0. 259p.

Büyükvelioğlu, E. (1998). A research on coastal management and planning in sustainable development in coastal areas. Unpublished master's thesis, Gazi University Institue of Science. Ankara Turkey.

DCT. (2006). Samsun Provincial Council for the Protection of Cultural and Natural Assets Report. Retrieved 2010. Samsun Turkey

Doğan, E., \& Erginöz, M. A. (1997). (in Turkish) Management and construction of coastal areas in Turkey. Arion Press, İstanbul, Turkey, 186 p. ISSN: 975-571-058-2 
Erginöz, M. A. (1998). Coastal use, management, decisions and recommendations in Mediterranean Countries and Turkey. Doctoral dissertation, İstanbul Technical University, 1998. İstanbul Turkey.

EUD. (2016). Sinop Province 2015 Yearly Environmental Status Report. Retrieved 2016. Sinop Turkey.

Gökkurt, Baki, O., \& Ergun, O. N. (2016). Investigation of integrated coastal management planning model-problems and solution alternatives. Journal of Coastal Zone Management, 2(19), 1-9. https://doi.org/10.4172/2473-3350.1000423

Gökkurt, Baki, O., Ergun, O. N., \& Bat, L. (2015). Sustainable Tourism Indicators and Coastal Management Plan in the South of the Black Sea. Journal of Coastal Life Medicine, 3(8). 600-606. https://doi.org/10.12980/JCLM.3.2015J5-28

Hudson, B. (1996). Cities on the Share. The Urban Littoral Frontier. Pinter. NewYork.

Işık, Ş. (2005). Urbanization and Urbanization Models in Turkey. Aegean Geographical Journal. Ege University Faculty of Literature Publications, 14, 57-71.

Koşar, G. (personal communication, May, 10, 2010)

Lamberti, A., \& Zanuttigh, B. (2005). An integrated approach to beach management in Lido di Dante, Italy, Estuarine. Coastal and Shelf Science, 62, 441-451.

https://doi.org/10.1016/j.ecss.2004.09.022

MEF. (2009). General Directorate of State Hydraulic Works. Presidency of Drinking Water and Sewerage Department. Sinop-Erfelek Dam Relief Facility and Treatment Plant Preliminary Report. Retrieved 2010. 392 p.

MSU. (2005). Study of Sinop Zoning Plan. Retrieved 2011. Mimar Sinan University, İstanbul, Turkey.

Official Journal. (1985). Law no:3194 Zonning Law, Turkey. Retrieved from http:mevzuat.gov.tr/MevzuatMetin/1.5.3621.pdf

Official Journal. (1990). Law no:3621 Coastal Law, Turkey. Retrieved from http:mevzuat.gov.tr/MevzuatMetin/1.5.3194.pdf

Tenikler, G. (2001). Coastal management for sustainable future in İmir Bay. Unpublished master's thesis, Dokuz Eylül University. İzmir Turkey.

Uçkun, E. (1988). Sinop Additional and Revision Construction Plan Explanation Report. Retrieved 2011. 73 p.

\section{Copyright Disclaimer}

Copyright for this article is retained by the author(s), with first publication rights granted to the journal.

This is an open-access article distributed under the terms and conditions of the Creative Commons Attribution license (http://creativecommons.org/licenses/by/3.0/). 